Not for quotation: a more recent version of this paper is under copyright. To obtain a copy for academic use, please email Eric Palmer.

\author{
Pre-proof copy, October 2002, forthcoming in: \\ International Corporate Responsibility: Exploring the Issues. John Hooker \& Peter \\ Madsen, eds. Pittsburgh: Carnegie Mellon University Press, forthcoming (2003).
}

\title{
Real Corporate Responsibility
}

\author{
Eric Palmer \\ Philosophy Department \\ Allegheny College \\ Meadville, PA 16335 USA \\ epalmer@allegheny.edu
}

The Call for Papers for this conference suggests the topic, "international codes of business conduct." This paper is intended to present a shift from a discussion of codes, or constraints to be placed upon business, to an entirely different topic: to responsibility, which yields duty, and the reciprocal concept, right. Beyond the framework of external regulation and codes of conduct, voluntary or otherwise, lies another possible accounting system: one of real corporate responsibility, which arises out of the evident capability of businesses to engage in rationally self-regulated activity. If such responsibility can be shown to be comprehensible, then it could bind the activities of corporations ethically, and in rationally compelling legitimate law, just as your activities and mine are bound.

Perhaps we can bind the officers of corporations as responsible persons, but I would like to introduce an undiminished conception of responsibility that will back legitimate law for the corporations themselves, as artificial persons. That is the purpose of Part 1 of this paper. In Part 2 I will turn to the case of multinational corporations in 
particular. I will draw conclusions regarding their general duties and rights, and will dip explicitly into ethical formulations, as well as the ground of legitimate law. I will also indicate a particular rational requirement, or duty, for politically and environmentally sustainable business practices of multinationals. In Part 3 I will discuss jurisdiction for instituting legal sanctions in multinational cases. I will argue that the national laws and civil suits that may be pursued within a court in one nation can actually stand as legitimate checks against abuses carried out by the arms of multinational corporations that reside in other nations.

\section{Part 1 Responsibility and corporate responsibility}

What is requisite for responsibility? Sections 1.1 and 1.2 will suggest an answer. The first sketches a current philosophical conception of how individual human beings - natural persons - are legitimately bound in just law, and the second presents my explanation of the basic conditions required for a parallel legitimate binding of the corporate business enterprise. The upshot, presented in section 1.3, is that because enterprises can rationally regulate their own behavior in order to act according to their perceptions of their own interests, they are capable of responsibility and acquire certain specific duties, including the maintenance of government.

\subsection{The framework of rational assent that supports legitimate law}

Ever since Thomas Hobbes, many have found political legitimacy to be a simple matter, at least in the abstract. In Hobbes, the key idea was that all who are governed should assent to government as a consequence of their own reasoning; otherwise, government should have no compelling hold on them. In Leviathan, Hobbes saw his job as showing individual readers, whatever their positions in society, that they should assent to government. Hobbes' general argument applied to almost any form of government that was in place, and to the laws that it imposed, because most government would serve the individual's most compelling interests by forestalling the severe dangers of anarchy. Jürgen Habermas has presented a descendent concept of legitimate law:

Social orders in which authority is organized through a state...experience a need 
for legitimation that is already implicit in the concept of political power. Because the medium of state power is constituted in forms of law, political orders draw their recognition from the legitimacy claim of law.

...a law may claim legitimacy only if all those possibly affected could consent to it after participating in rational discourse. ${ }^{1}$

I consider each of these to be a framework of rational assent for political legitimacy because each bases legitimacy in the assent of every concerned party at the outcome of reasoned discourse. If rational assent is required for legitimate law, coercion cannot be the complete grounding for just laws, even though policing may be necessary to produce obedience. In an example from Hobbes, fear of the danger inherent in disobeying a pitiless or even pathological tyrant does not serve to justify the citizen's adherence to imperfect government; but an intellectual grasp of the greater danger inherent in the total failure of government does. ${ }^{2}$ Habermas explains the general requirement thus:

Legal norms must be so fashioned that they can be viewed simultaneously in two different ways, as laws that coerce and as laws of freedom. It must at least be possible to obey laws not because they are compulsory but because they are legitimate. $^{3}$

Absence of the backing provided by compulsion - what Hobbes refers to as the sword of the sovereign - would yield law that is toothless; absence of legitimacy, of sufficient grounds for assent, would yield law that is unjust. Habermas' concept of legitimacy as the product of consent that follows upon rational discourse presents a key concept for this paper, to accompany responsibility, to which I now turn.

\subsection{Between Scylla and Charybdis: what is corporate responsibility?}

Responsibility is grounded in autonomy, or practical self-regulation. Corporate responsibility, to be responsibility and not something less, would have to deviate from reliance on regulation from the outside (by government), and from utterly unregulated activity that is destructive, and consequently self-destructive. Scylla, in this tale, is 
external regulation without the rationale of legitimacy that might provide the impetus for self-regulation. Charybdis is irresponsibility: short-sighted abandon in the absence of regulation that reflects an inability to engage in reasoned self-regulation. Real responsibility must steer between these two hazards.

Milton Friedman presents an example of a discussion of responsibility that courts external regulation, and so does not represent real corporate responsibility. ${ }^{6}$ Friedman is an advocate of the position that executives have the exclusive responsibility of promoting egoism "within the rules of the game" in the corporate setting:

...there is one and only one social responsibility of business - to use its resources and engage in activities to increase its profits so long as it stays within the rules of the game, which is to say, engages in open and free competition, without deception or fraud. ...Few trends could so thoroughly undermine the very foundations of our free society as the acceptance by corporate officials of a social responsibility other than to make as much money for their stockholders as possible.

Hobbes would have us realize that reason must rein in some behavior to promote egoistic action. Friedman's reference to the "rules of the game" might suggest agreement, but he does not clearly credit the executive branches of corporations with the responsibility to set the rules. Though he finds it a duty of corporate officials to curtail deception and fraud, he places the ultimate responsibility for all rules upon neither natural persons such as the officers of a corporation, nor corporations, but rather, upon citizens and legislature:

It is the responsibility of the rest of us to establish a framework of law such that an individual in pursuing his own interest is, to quote Adam Smith again, "led by an invisible hand to promote an end which was no part of his intention..."7

Thus, Friedman has characterized corporations as egoistic, but he grants neither the corporations nor their executive, in their capacity as executive, the full responsibility that Hobbes and Habermas feel is due to rational actors. As a consequence, corporations and executive are to be externally constrained by egoistic, rational citizens, and law need not be shown to be legitimate from the corporation's perspective. The ultimate hold of 
law on corporations, then, is pure coercion: it is not legitimate, for it is not reasonable, from the corporate perspective. Despite Friedman's claim, the hand that leads corporations in his account must be a clearly visible and external one.

My hope is to improve upon that approach. Rational constraint, or justification as seen from the point of view of the corporation, might be offered in place of imposed constraint that ignores the corporate perspective. The approach might also improve upon voluntary codes of conduct adopted by businesses, which may remain legitimate in Friedman's account even if they arbitrarily address only perceived harm and public demands, ${ }^{8}$ rather than a reasoned restraint that would produce a functional fit with effective corporate activity. Even Friedman might approve the result: first, the functional fit would improve over-all efficiency; and second the result would be consistent with the first quotation from his writing presented above.

\subsection{Binding corporations}

Having sketched accounts of justice and responsibility, at this point I will hop over a good deal of philosophical argument that I would make for other audiences. That argument would be careful work to dispel the apparent oddity of applying terms such as 'point of view,' 'rationality,' 'interest,' 'planning,' and 'action' to corporations, as distinct from their owners or executive. ${ }^{11}$ Here I will simply suppose that what many would take to be metaphorical may instead be understood literally: that corporations have the ability for planning regarding their actions, and so have the capacity for responsibility as self-regulation that I have sketched in section 1.2. I do not wish to suggest that corporations themselves have minds in which they accomplish the planning, or spend time worrying about other corporations or dreaming of mergers: I merely suggest that we can appropriately treat the corporations as having the ability to plan, through their executive. That a plan for one corporate action may be carried through by a team of executives, none of whom need have a complete grasp of the entire plan, or have control of all parts of the action, is enough to make the point. And I take the point to be 
important, if we are to claim that corporations, as distinct from their executive, can be responsible and have duties (and the converse of duties - rights).

Hobbes argued that it is in the interest of each of us to uphold government in all situations. He brooked exceptions, such as the convict condemned by laws to death, but he asserted that in most situations only a fool who is making a mistake chooses to disobey the law. Hobbes argued that any gains from lawbreaking simply could not match the danger of losses that would be incurred in the anarchy that it might promote. It simply could not be in one's rational self-interest to break the law. ${ }^{12}$

Are the responsibilities similar for corporations in such a Hobbesian analysis? Corporations benefit from government, for they could not possibly exist without it, so the answer is clear: if they are interested rational agents, then interest clearly points towards the maintenance of government. Corporations, even more so than natural persons, ought to be inclined by reason against lawbreaking. So goes the case for the relation of corporations to government: we have something much like Hobbes' argument, that government is necessary to flourishing for the corporation, and so, it is in the corporation's interest to preserve it, much as it is in the individual human's interest.

Multinational corporations might present an exception, however. As armies may do in war, multinationals might rationally choose to sacrifice a part for the greater advantage of the whole, and that part may be an arm within a nation. Though the maintenance of government remains in a corporation's interest, for example, it is not obvious that the maintenance of any particular national government need be in the corporation's interest. And indeed, there have been notorious cases in which corporations have taken it to be in their interest to manipulate or even destabilize government. ${ }^{13}$ Because of the opportunity presented by rapacious exploitation and subsequent withdrawal, a multinational business might destabilize the government in one country and live to exploit another day in many others. But could multinationals be acting responsibly - that is, in their long-term self-interest (Hobbes) or as reasoning parties (Habermas) - if they do so? 


\section{Part 2: Duties and rights of multinational corporations}

If corporations within nations are rationally bound to uphold stable government, as I have argued above, one might expect that multinational corporations would have a similar status among nations. Multinationals would, then, be bound to the laws of the states within which they reside as corporations, and such behavior has heretofore been expected of them. Union Carbide is legally - and, on the face of it, also rationally bound to adhere to Indian environmental and labor standards in India, and Indonesian standards in Indonesia. Call this the nationality expectation of corporations.

Multinationals have the capability to pick and choose, however, exploiting the lax environmental standards here and the low wages there to manufacture their products with maximum advantage. Call this the national exploitation expectation of corporations. They might also attempt to manipulate tax advantages by setting up shell companies, by skirting arm's length rules for the international trade of goods internal to the corporation, ${ }^{15}$ and by many other ruses not dreamt of by a philosopher. Call this the international exploitation expectation of corporations.

All of these expectations need careful examination when corporations are multinational. In the previous section, I cast the nationality expectation into doubt for the multinational case, but I believe that it can be re-established through argument I will pursue below. Both exploitation expectations seem, at first glance, to be in the interest of multinational corporations. I shall argue that they are not, in their extreme forms: only strictly limited exploitation by any corporation can be considered responsible by that corporation. One illustrative restriction that I will suggest is globally sustainable activity.

\subsection{Multinational responsibility: Duties ${ }^{16}$}

Though laws are primarily set at the level of nations, that presents no reason why the reasoned basis of law should not be considered more broadly - at a multinational level - by those with the capacity to act multinationally. This points to a justification and rationalization for more universal standards: multinational agents are rationally bound to consider the legitimation of law trans-nationally. ${ }^{17}$

Multinational entities are in a special position: given their multinational presence 
and their ability to withdraw from individual nations while retaining their integrity, they stand beyond the level of national governments. So how might they go about establishing supra-national standards of conduct that are in accord with reason? This becomes a particularly acute problem where the standards of different nations, to which the corporations must comply, come into conflict: some may be stricter than others, and some may straightforwardly contradict others. A thorough treatment of the standards that a multinational corporation must abide by would require an extended treatment by itself, and contradictory standards pose a particularly difficult case. But one general governing principle for such an account can be put quite briefly: a multinational corporation must act according to standards that promote global sustainability.

If a multinational did not act according to a requirement of sustainable activity, it would present the threat of destabilizing government, an outcome which cannot be in any corporation's interest (and similarly, not in the rational self-interest of any corporate owner or shareholder). A short-term and localized strategy of non-sustainable but highly profitable exploitation might appear, at first glance, to be in the interest of a multinational corporation, since the corporation could withdraw from the local area after engaging in ruinous behavior. Such a strategy fails, however: the multinational corporation would face the prospect of other multinational corporations engaging in ruinous exploitation, and consequently destabilizing the governments of all nations, including the nations that other corporations might expect to use as the bases of their retreats. And so, such activity would indirectly promote a corporation's own dissolution.

Sustainability may be taken to ordinarily demand either stability or growth for all of the economic resources necessary for running a business, including the treatment of workers and the treatment of the laws of national governments. Further flexibility might be warranted in a context of innovation, however. A corporation might be in a position to show that non-stable activity can nonetheless be sustained by, for example, ongoing technology implementation, or retraining of workers. So, I suggest a normative stability model for sustainability: sustainability and stability should be normatively linked in the absence of explicit demonstration that sustainability does not require stability. This model has the advantage of producing an effective counter to extended, non-sustainable 
exploitation of resources without presupposing an inflexible, prior delineation of conditions for sustainable use. If the burden rests with the corporation to show that destabilizing activity can nonetheless be sustained, then a useful starting position for legal treatment of global sustainability is available.

\subsection{The other side of responsibility: Right}

The specific fruits of self-regulation are both duties and rights, and so we may expect corporations to be in a position to claim rights as well as be obliged to duties. There are fundamental differences between natural and artificial persons, however, and a crucial distinction is that there is no reason to maintain that artificial persons such as corporations are creatures of inherent value, or, as Immanuel Kant puts it, "ends in themselves." I have sketched a detailed philosophical account of this difference and of its ramifications for rights in another place, ${ }^{18}$ so here I will consider the status of corporations with respect to rights in more casual terms.

A few examples will illustrate that the rights of different sorts of natural and artificial persons will diverge in many respects. Consider as examples two human rights that are broadly accepted within civil society: the right of a human to safety and "security of person," and the right to education. Both of these are recognized as rights in the United Nations Declaration on Human Rights. ${ }^{19}$ Neither of these rights applies to multinational corporations, as far as I can tell, for the simple reason that they could not be applicable: I am left utterly in the dark as to what 'safety' or 'education' could be, in such cases. Now consider their application to animals, some of which have also been considered plausible candidates for personal, individual rights. I believe that even the most extreme of animal rights advocates would accept that, though a right to security of person in civil society is required for many or even all non-human animals, a personal right to education is not. So, these several example cases illustrate that some personal rights, such as the right to education, might be applicable only to some natural persons, and that other personal rights, such as the right to security, might be applicable only to natural persons generally. Neither of these rights would be applicable to corporations, nor to any artificial persons, if we exclude from this discussion the speculations of artificial intelligence researchers concerning far-off possibilities. 
The key difference between natural and artificial persons illustrated by these examples has been characterized clearly in the work of Immanuel Kant. It is the difference between 'ends in themselves' and mere 'rational agents,' and it is a difference that is reflected in the twin formulations of Kant's ethical theory. Artificial persons may be considered to be rational agents; that is, they can, through their executive, deliberate on actions and the general ramifications of actions. Kant writes of rights and duties of nations, ${ }^{20}$ and I suggest that businesses fit similarly. The business plan for development of a company is an example of deliberation that may come to be put into action, and in such planning, the effects of actions on others may be entertained. Thus, corporations can, through their executive, entertain the consequences of their actions. They can also change course as a result of those deliberations, and so they qualify as rational agents. This implies that corporations fit as agents who can act according to the first formulation of Kant's categorical imperative:

Act only in accordance with that maxim through which you can at the same time will that it become a universal law. (4:421)

But artificial persons such as nations and corporations are not, by contrast, ends in themselves: they are of instrumental, and not ultimate or intrinsic value. This point might be taken as simply obvious, for they lack the feeling or mind that we might take to be the seat of value, and they lack the deliberative will that Kant takes to be the relevant marker in his account. ${ }^{21}$ Thus, they should not be considered to be members of the group that falls under consideration in Kant's second formulation:

So act that you use humanity, whether in your own person or in the person of any other, always at the same time as an end, never merely as a means.

The individual who can deliberate on ends is "destined by his own nature as being an end in himself and, on that account, legislating in the kingdom of ends." ${ }^{22}$ Though Kant uses the expression "humanity" in this instance, he often substitutes the broader term "rational beings" ${ }^{, 23}$ in its place, and clearly intends to allow the concept a broader application than the human, if a broader use may be found to be applicable. Thus, a Kantian who 
considers some non-human animals to be persons would stick to a formulation in terms of rational beings. ${ }^{24}$

Artificial persons, then, have their place in a fully thought-through ethical system. That place provides them duties as rational agents who can foresee the effects of their actions, without the rights that accrue to ends-in-themselves. Do there remain any rights that artificial persons retain? If right is based in intrinsic value, and responsibility is based in intrinsic capacity, it might just be the case that artificial persons have responsibilities without right: they have duties, but can make no demands. This one-sidedness might not seem particularly odd, if we note that the reverse of this situation, rights with no correlate responsibilities, may be considered to be appropriate for infants and perhaps for some animals. What motive could corporations have for remaining in such a one-sided arrangement, however, if they do not maintain rights? I hope that the answer is obvious, by this point: they don't have a motive, but they are also not the sorts of things to have any sort of motive or mind at all. Furthermore, in the Kantian ethical system that I have articulated here, as opposed to the Hobbesian system considered earlier, self-interest, or prudence, can play no role in ethical evaluation.

I do believe, however, that a case can be made for recognizing limited rights for corporations. The argument draws by analogy from Kant's account of the rights of nations:

There are no limits to the rights of a state against an unjust enemy...that is to say, an injured state may not use any means whatever but may use those means that are allowable to any degree that it is able to, in order to maintain what belongs to it. --But what is an unjust enemy in terms of the concepts of the right of nations...? It is an enemy whose publicly expressed will (whether by word or deed) reveals a maxim by which, if it were made a universal rule, any condition of peace among nations would be impossible... (M 349)

Kant's endorsement of the language of right and of will with respect to nations leads me to suggest that a general accounting of the rights of corporate bodies - businesses as well as nations - should be considered for any Kantian legal theory. The concept of an 'unjust enemy' may be re-cast with respect to sustainable activity in businesses, and of nations and individuals, in terms of activity violating the first Categorical Imperative. A nation may pursue redress by right through war, as Kant implicitly suggests above, and 
similarly, redress is generally open to businesses and individuals by the alternative process of the courts in civil society.

An alternative and superior relation available to nations lies in what Kant calls the cosmopolitan ideal of a federalism of free states - an assembly of united nations that banishes war. ${ }^{25}$ Though Kant did not develop the point, I would like to suggest that businesses free of single nation ties (that is, multinationals) may have a distinct role in multinational arrangements that is to be integrated with that of the assembly of nations. A portion of that role is indicated in the following section.

\section{Part 3: Multinational law: jurisdiction and enforcement}

My main concern has been to show how the basis for law in frameworks of rational assent can involve legitimacy from the perspective of the multinational corporation. The ground of legitimacy that binds the corporation as an artificial person lies in the rational responsibilities of the corporation, on this view, and not in the supposed prior jurisdiction of national law. And I suggest that national law doesn't have ultimate rational jurisdiction, just because of the multinational character of the corporation. The ability of the multinational to successfully withdraw from any nation, and also the rational demand that it look to a multinational picture when framing duty, calls national jurisdiction into question. This suggests the necessity of a sphere of multinational jurisprudence. How could multinational law be articulated, however? How would decisions be made (what jurisdiction?), and how would they be enforced?

Concerning enforcement: Trans-national bodies such as the United Nations and the World Court have had some success at promoting and receiving recognition for

universal legislation and rulings, ${ }^{26}$ but subscription to their decisions will inevitably remain a weak point in a world of independent governments. Though nations and their citizens have, at times, ignored trans-national judgments on their behavior, an isolationist strategy should be much less effective for entities with arms in many nations. The problem of enforcement - the necessary aspect of law that Habermas refers to as compulsion, and Hobbes refers to as "the sword" of the commonwealth - remains a 
significant problem in the absence of a sufficient trans-national police force, however. Though trans-national juridical and enforcement bodies are conceivable solutions to the problem of order, the multinationality of corporations suggests another solution to order that is available at the national level.

To solve the general problem of order (jurisdiction + enforcement), I must turn to jurisprudence. Practical rationality from the multinational perspective would allow that a proper jurisdiction lies within each of a multinational corporation's resident nations for enacting judgment and enforcement on action in every nation within which it resides. How would multinational law be articulated in the absence of a trans-national legislative body? It could begin from philosophical principles such as the normative stability model, but would develop as case law, through judgments. The legal theorist's role would be to debate the rational appropriateness of principles from the multinational perspective. If general guidelines such as the normative stability model are articulated and found to be acceptable by theorists, then multinational law could develop through challenges to corporations beginning from the guidelines. The law would take the form of a changeable body of precedents arising out of the guidelines, which might be accepted by subscription, or may also be open to consideration in the courtroom. By its essence, multinational law would be concerned with the multinational perspective: it would consider, for example, political and environmental sustainability over the entire set of nations in which a multinational entity is involved at the time of an action under consideration for legal sanction. Advocates for opposing parties would, then, argue the merits and failings of a particular business practice with respect to that multinational perspective.

Concerning legal jurisdiction, I can find no reason in the case of a multinational concern (as opposed to a universal concern of right, or a concern between nations regarding government) to privilege international court over courts within any nation in which an arm of the multinational resides. ${ }^{27}$ Placing cases at the national level would also provide obvious advantages for enforcement. A multinational violation, such as a breach of sustainable activity within a collection of nations, impinges upon the group, and so might be dealt with by the group, in an international court (or a universal court). But the 
violation also impinges upon nations as members of the ecological unit, and upon individual citizens of those nations as members of the nations. It would appear reasonable that charges may legitimately be brought from any or all of these levels. A governmental or non-governmental organization, a corporation or even a private citizen, then, might indict a multinational corporation in national civil court for inappropriate action carried out in another nation. The defendant for such an indictment would be an arm of the multinational entity, the artificial person that resides within the organization's or the citizen's home country.

The problem of enforcement can be solved much as the problem of jurisdiction was solved, by exploiting the multinationality of such corporations. If national enforcement can be realized, then trans-national standards of conduct may never demand enforcement above the level of independent nations. Given that a lack of enforcement could damage government, it is in the interest of nations and of individual members of nations to enforce such laws at the national level. I suggest, then, that reason demands jurisdiction and the appropriateness of sanction and enforcement within each nation of residence of a multinational entity.

Three concluding remarks regarding jurisdiction are in order. First, I should explain the concept of jurisdiction I have invoked, in light of what I have referred to as legitimacy with respect to the 'perspectives' of governments, citizens, and corporations. If legitimacy is to be understood as Habermas presents it - as grounded in the outcome of rational discourse among affected parties - then legitimate legal jurisdiction becomes a concern that is relative to the perspectives of the individual bodies that are concerned in the case. Trans-national government with an effective police force would certainly serve as one effective legislative enforcement method, but such a solution is not actually required to solve the problem of order in a way that satisfies legitimacy if we take perspectives into account. Indeed, such an additional trans-national structure would yield yet another perspective, and complicate matters.

Second, the proposed national solution to jurisdiction clearly runs afoul of a simple interpretation of the jurisprudential principle of forum non conveniens: that the court of one nation is not the legitimate place to consider whether activity in another 
nation is appropriate. Yet the principle is, of course, often overridden in two cases: where human rights are violated, and where harm is done to members of the distant nation. ${ }^{28}$ If jurisprudence regarding legitimacy may be grounded in argument from the framework of rational assent as it has been developed here, then fora should be reconsidered.

Third, I should note that the national solution for jurisdiction that I have sketched here can only apply to multinational non-governmental corporate entities. It does not sanction attacks pressed by a nation or a citizen against governmental action within a distinct, sovereign nation's borders. It also does not sanction penalty or direct seizure of the assets of a multinational that belong to arms that lie outside of the country in which prosecution occurs. Successful prosecution within one nation concerning a multinational corporation's behavior elsewhere might often be perceived as implicit criticism of one government's integrity or policies by another. Judgment is found only against the multinational corporation, however, and does not provide for seizure of assets within that other country. Such a solution has the advantage of allowing collusion between enterprises and corrupt or inept governments to be judged outside of the jurisdiction of the courts of those governments. Of course, those advantages also come with attendant disadvantages in a political world.

\footnotetext{
${ }^{1}$ Jürgen Habermas, "Remarks on legitimation through human rights," Philosophy and Social Criticism 24 (1998): 157-71. See 157, 160. For this brief presentation, I will restrict myself to discussion of Habermas' account of practical reason, and forego communicative reason. For differences, see Habermas, Between Facts and Norms: Contributions to a Discourse Theory of Law and Democracy, trans. William Rehg (Cambridge, MA: MIT Press, 1996), pp.1-4.

${ }^{2}$ Thomas Hobbes, Leviathan [1651], ed. Edwin Curley (Hackett, Indianapolis: 1994), I.XX.2.

${ }^{3}$ Jürgen Habermas, "Remarks," 158. And compare Immanuel Kant, Metaphysics of Morals, 6:232. Pagination for this and all other works of Kant refer to the standard Prussian Academy of Science (1907) edition of Kant's work. Translations are from the edition of Mary Gregor: Immanuel Kant, Practical Philosophy (UK: Cambridge University Press, 1996), in which the standard pagination may also be found.

${ }^{4}$ See John Rawls, A Theory of Justice, (Cambridge, MA: Harvard University Press, 1971); Otto Gierke, Natural Law and the Theory of Society, trans. E. Barker (Cambridge, UK: Cambridge University Press, 1913).
} 
${ }^{5}$ Hobbes, I.XV.2: "For where no covenant hath preceded, there hath no right been transferred..."

${ }^{6}$ Milton Friedman, Capitalism and Freedom, (Chicago: University of Chicago, 1962).

${ }^{7}$ This quote and previous quote, Friedman, p. 133.

${ }^{8}$ On the inadequacy of the approach of voluntary codes, see International Council on Human Rights Policy, Beyond Voluntarism: Human rights and the developing international legal obligations of companies. (Versoix: ICHRP, 2002), pp. 18-19, 70. All ICHR publications are also available at http://www.ichrp.org.

${ }^{9}$ Organization for Economic Cooperation and Development, Declaration by the Governments of OECD Member Countries on International Investment and Multinational Enterprises. OECD Working Papers 5, \#20 (Paris: OECD, 1997), Annex I, 7, p. 9.

${ }^{10}$ A rationale is offered in a companion OECD document, The OECD guidelines for multinational enterprises, and it merits a brief note. The rationale provided in that document is the suggestion that adherence to the entire body of guidelines "can help prevent misunderstandings and build an atmosphere of mutual confidence and predictability between business, labor, and governments." The OECD does not aspire to draw enterprises into these restrictions without complementary efforts on the side of the nations: it cites OECD guidelines that nations are to follow as well.

${ }^{11}$ Such argument is presented in Eric Palmer, "Corporate bodies and categorical imperatives," in Kant und die Berliner Aufklärung, Akten des 9. Internationalen KantKongresses, 2000. Willem deGruyter: Berlin, 2001.

${ }^{12}$ Hobbes, I.XV.4-5: “...he which declares he thinks it reason to deceive those that help him can in reason expect no other means of safety than what can be had from his own single power. ...if he be left or cast out of society, he perisheth; and if he live in society, it is by the errors of other men, which he could not foresee nor reckon upon; and consequently against the reason of his preservation..." The (very) roughly analogous argument in Habermas, which does not invoke self-interest exclusively, may be found in "A genealogical analysis of the cognitive content of morality," reprinted in Habermas, The Inclusion of the Other: Studies in Political Theory, Ciaran Cronin and Pablo De Greiff, eds. MIT: Cambridge, 1998, pp. 3-4.

${ }^{13}$ The history of concerted universal concern for thest problems dates to about 1972, with a complaint before the UN Economic and Social Council by Chile against International Telephone and Telegraph Company. See Hans Baade, "Codes of Conduct for Multinational Enterprises: An Introductory Survey," in Norbert Horn, ed. Legal Problems of Codes of Conduct for Multinational Enterprises, (Deventer, The Netherlands: Kluwer, 1980), pp. 414ff. For a case study, see Manuel Velasquez, "International Business Ethics: The aluminum companies in Jamaica," Business Ethics Quarterly 5, 1995, pp. 865-70.

${ }^{14}$ It should be noted that some multinational entities, since long before Hobbes' time, have maintained some of the advantages that multinationals enjoy today. One evident example is the Fugger banking concern in medieval Europe. See Jacob Strieder, Jacob Fugger the 
Rich, Mildred L. Hartsough, trans. (USA: Adelphi, 1931). Edwin Hunt, The Medieval Super-Companies, (USA: Cambridge, 1994).

${ }^{15}$ See Organization for Economic Cooperation and Development, "Taxation," 2, p.12.

${ }^{16}$ Some argument and text in sections 2.1 and 3 are drawn directly from Eric Palmer, "Multinational Corporations and Social Contracts," Journal of Business Ethics 31 (May 2001): 245-58.

${ }^{17}$ The term 'trans-national' is used here to indicate universal relations that apply either across all nations of the globe, or to all nations of direct relevance to the operation of a multinational entity. 'International' is used to indicate relations among specific independent national governments. For example, the OECD is constituted by international agreement among governments of member nations, whereas human rights are held by many to be a trans-national relation, and a universal one.

${ }^{18}$ Palmer, "Corporate bodies and categorical imperatives."

${ }^{19}$ The.1948 Universal Declaration of Human Rights, Articles 12, 3, 26.

${ }^{20}$ E.g, Metaphysics of Morals, 6:349.

${ }^{21}$ Groundwork, 4:393.

${ }^{22}$ Groundwork, 4:435

${ }^{23}$ Groundwork, 4:408.

${ }^{24}$ I have referred to corporate bodies as "rational agents" above, so my terminology is a bit askew of Kant's here. Kant does, however, make the distinction, distinguishing between beings of intrinsic value and "things" such as countries with rights and duties, yet no rights against those beings of intrinsic value. (Metaphysics of Morals, 6:349,358)

${ }^{25}$ See Kant, "Toward Perpetual Peace," esp. Second Article, 8:354 and 8:386.

${ }^{26}$ See International Council on Human Rights Policy, Hard Cases: Bringing Human Rights Violators to Justice Abroad - A guide to universal jurisdiction, (Versoix: ICHRP, 1999).

${ }^{27}$ Placing decisions in national courts seems a conceptually superior strategy to international court, in fact. There appears to be no rationale, from the multinational perspective, for judging multinational entities in the courts of a consortium of nations. By contrast, the reasoning behind prosecution at the national level is quite clear, and should command respect by the multinational entity.

${ }^{28}$ See International Council on Human Rights Policy, Hard Cases; Jeremy Seabrook, No Hiding Place, Zed: London, 2000; and Mark Gibney, ed. World Justice? Westview: San Francisco, 1991. 